\title{
Literature Review on the Independence and Effectiveness of Independent Directors
}

\author{
Tingyou Deng \\ Jinan University, Guangzhou, China \\ Email: 389649335@qq.com
}

How to cite this paper: Deng, T.Y. (2019) Literature Review on the Independence and Effectiveness of Independent Directors. Open Journal of Business and Management, 7, 1063-1071.

https://doi.org/10.4236/ojbm.2019.72072

Received: March 27, 2019

Accepted: April 25, 2019

Published: April 28, 2019

Copyright $\odot 2019$ by author(s) and Scientific Research Publishing Inc. This work is licensed under the Creative Commons Attribution International License (CC BY 4.0).

http://creativecommons.org/licenses/by/4.0/

\begin{abstract}
This paper summarizes the literature on the independence and effectiveness of independent directors, finds indicators of independence and effectiveness, and finds the connection between the two.
\end{abstract}

\section{Keywords}

Independent Directors

\section{Introduction}

The full implementation of the independent director system is an important Open Access 


\section{The Rise of the Independent Director System}

Mace's (1971) [2] survey of executive and non-executive directors of large US companies shows that directors of US companies are primarily selected by the company's president rather than shareholders, which means that in reality, directors represent the president rather than the shareholders. As a result, directors are unlikely to challenge management decisions or give management problems. In Canada, the Lawrence Commission Report emphasizes the importance of non-executive directors to the company's performance improvement. Tricker believes that the UK's board of directors must break the situation dominated by executive directors, and independent directors should dominate the board so that the board can strike a better balance between the management's expertise and the independence and objectivity of independent directors. This balance is a necessary condition for the board to make the right decisions. The famous management master Peter Drucker [3] believes that the role of the board of directors in the development of the company has given way to management. Drucker attributed the decline in the board's role to three factors: the further separation of ownership and management of modern companies, the increased complexity of modern business operations, and the difficulty of finding suitable candidates who are willing to invest time and energy as directors. Jensen (1993) argues that an effective board organization model should be to maintain a smaller board size, with the exception of the CEO being the only internal director and the rest being external directors.

In China, "Tsingtao Brewery" was listed on the Hong Kong Stock Exchange in 1993, creating a precedent for the introduction of independent directors in listed companies in China. Later, listed companies actively introduced independent directors in the board of directors. In December 1997, the China Securities Regulatory Commission issued the "Guidelines for the Listing of Listed Companies". On March 29, 1999, the former State Economic and Trade Commission and the China Securities Regulatory Commission issued the "Opinions on Further Promoting the Standardized Operation and Deepening Reform of Overseas Listed Companies". "There is a reference to the independent director system. In August 2001, the issuance of the "Guiding Opinions on Establishing an Independent Director System in Listed Companies" by the China Securities Regulatory Commission marked the announcement of the full introduction of an independent director system among domestic listed companies. The "Guidelines for the Governance of Listed Companies" issued in January 2002 also explicitly mentioned the independent director system.

\section{Independence of Independent Directors}

Independence is considered to be the core and soul of the independent director system. For the independent director system, the core of its vitality and effective functioning is "independence". The early literature mainly used the proportion of independent directors on the board of directors as a surrogate variable to 
measure the independence of independent directors. (Cotter et al., 1997 [4]; Weisbach, 1988 [5]; Bhagat and Black, 2002 [6]) Yiming Hu and Songlian Tang examined the relationship between independent directors and the quality of earnings information of listed companies, and found that independent directors with financial or accounting background, independent directors in the board of directors accounted for a relatively high proportion, and listed companies had better earnings information. In recent years, the measure of the independence of independent directors has gradually changed. Kangtao Ye and Jigao Zhu used the data of independent directors of Chinese listed companies to express their opinions and vote on the board of directors, examining the independence of independent directors from management and their supervisory role, and found that in most cases, independent directors would not openly questioning management's behavior, when the company's performance is not good, the independent director is more likely to openly question the management's behavior; and the higher the reputation, the financial background, the independent director who has served before the chairman's appointment time is more likely Questioning management decisions. Quanxi Liang and Haijian Zeng used the unique independent directors of listed companies in China to express their opinions and vote on the board of directors, and examined the impact of the independence of independent directors on management on the stock price collapse risk. In the absence of a company that disagrees with an independent director, there is a significant risk that the share price of the dissenting independent director company will collapse.

In addition to directly examining the supervisory role of independent independence, there is also a literature that explores the interaction between independent directors and internal and external factors. Changwen Zhao explores that independent directors in family businesses will play a more active role in corporate governance. Zhigang Zheng and Xiuhua Lu also examined the role of the interaction between the independent director system and other systems within the company on corporate governance. They concluded that the governance effects of the independence of the board of directors and the governance mechanisms of major shareholder supervision and management compensation incentives are mutually reinforcing (complementary), and there is an alternative relationship with the governance mechanism of the protection of investor power and equity checks and balances. The implementation of China's independent director system will improve the governance effect of major shareholder supervision and management compensation incentives, but to a certain extent will weaken the governance effect of legal environment improvement and equity checks and balances. The corporate governance effect of the independence of the board of directors is not directly, but indirectly through the interaction with other governance mechanisms to play a role in corporate governance. $\mathrm{Xi} \mathrm{Wu}$, Chunfei Wang and Zhengfei Lu studied the three modes of the company's independent directors and auditors from the perspective of accounting professional 
background. The first model is that the company hires employees from the chief audit firm to serve as independent directors (the "same door" model). Under this model, there is a higher level of cooperation between the independent director and the auditor, but its independence declines. The second model is that the company employs individuals who have worked in the firm as independent directors ("pre-peer" model). Under this model, the independence of the independent director and the auditor is significantly enhanced, and the degree of cooperation is also high. The third mode is that the independent director hired by the company is working in the firm, but not from the chief audit firm ("peer" mode). Under this model, although the independent director is independent of the auditor, it poses a competitive threat to the auditor, which may weaken the auditor's motivation and effect on the client's supervision. Three different models have different effects on the independence of independent directors. At the same time, Rui Chen and Zhi Wang discussed the consequences of independent directors' independent opinions. The study found that in the group of listed companies challenged by independent directors, the "reverse elimination" effect is very serious, and the probability of leaving independent directors is significantly higher. And its successor's independence and reputation are low. The number of positions of independent directors who subsequently obtained independent directors of other companies was significantly lower than that of unemployed independent directors.

Due to the lack of understanding of the actual decision-making process of the board of directors, some studies examine whether the independent director system can alleviate agency problems by directly examining the correlation between the proportion of independent directors and company performance. However, since the proportion of independent directors and corporate governance agent variables are likely to be related to missing variables, this research method is prone to serious endogenous problems (Hermalin and Weisbach, 2003 [7]). Pettigrew (1992) [8] further pointed out that when there is no direct evidence about the decision-making process of the board of directors, if the researchers directly examine the relationship between the proportion of independent directors and the company's performance, it is easy to lead to excessive logic jumps, and it is recommended that future research be necessary to conduct in-depth investigations. The actual decision-making process of the board of directors. This paper uses the research opportunities provided by China's unique mandatory disclosure data (that is, independent directors' opinions and voting results on the board's resolutions), and measures the independence of the re-elected directors by re-electing the objections expressed by the independent directors.

\section{Effectiveness of Independent Directors}

Fama and Jensen (1983) provide detailed theoretical explanations for ownership and control of the company. They pointed out that granting decision-making management rights to managers and granting decision-making control to the board 
of directors can alleviate agency problems. However, if the manager controls the board at the same time, the manager may collude with the board to exploit the dispersed shareholders. Independent directors enter the board of directors and play a supervisory role to protect shareholders' rights from management's infringement.

The existing research mainly discusses the governance role of independent directors from the two functions of supervision and consultation.

Whether the introduction of independent directors can effectively protect the interests of investors and improve the company's performance has always been one of the hot research topics of corporate governance scholars. However, the existing research has not reached a consensus conclusion. Some studies have found that the proportion of independent directors on the board of directors is significantly positively correlated with business performance (e.g., Brickley et al., 1994 [9]; Peng, 2004 [10]). However, some studies have found that there is no positive correlation between the two (for example, Adam and Ferreira, 2007 [11]).

Adams et al. (2010) [12] believes that the supervisory function of independent directors is mainly reflected in the selection, evaluation and dismissal of management to reduce the agency costs between management and shareholders. Weisbach (1988) found that independent directors can enhance the relationship between CEO turnover and company performance, and remove incompetent CEOs. Core et al. (1999) [13] found that independent directors can suppress CEOs from receiving excess compensation. However, these documents are based on developed markets, with the first type of agency problem (the conflict of interest between management and shareholders); when the research perspective shifts to the second type of agency problem (the conflict of interest between major shareholders and minority shareholders) After the dominant emerging market countries (including China), the supervisory function of independent directors mainly lies in how to curb the large shareholders' encroachment on minority shareholders. Dewu Zhao empirically verified the significant positive impact of independent directors' supervisory power on earnings robustness through factor analysis and path analysis. Some documents measure the supervisory role of independent directors through corporate violations. Chunmei Zheng found that the frequent absence of independent directors is high, and the possibility of violations by the company is large; the opposition of independent directors during their term of office often means that the company is more likely to violate the rules.

Due to the disparity in the background of independent directors, research has further examined the relationship between the personal characteristics of independent directors and company performance. These studies are mainly from gender (Adams and Ferreira, 2009), education and work background (Rosenstein and Wyatt, 1990 [14]; Fich, 2005 [15]), concurrently holding director positions in other companies, tenure and network location and other perspectives, as well as the consequences of accounting professionals as independent directors 
(DeFond et al., 2005 [16]). At the same time, due to the "resignation tide" of the official directors of China, there are also a series of studies on the role of independent directors in the background of administrative officials. In general, these studies suggest that the independent directors' supervision of the background of officials weak.

A part of the literature mainly explains the effectiveness of the independent system through the supervisory path. Another part of the literature explores the advisory mechanism for the effectiveness of the independent director system. According to a survey by Demb \& Neubauer (1992) [17], most independent directors agree with the consulting role, that is, using professional talents to make suggestions for company strategy formulation and project selection. Adams \& Ferreira (2007) believes that the premise of independent director supervision is to grasp the real situation of the company. Too much independence will result in management's reluctance to share internal information, which is not conducive to the function of consultation (Coles et al. (2008) [18]). The more complex the company's business is, the more independent directors will be hired. Hao Liu and Song Tang took the independent directors of the bank as the research object. The empirical test found that the advisory function of the independent directors of the bank background was more obvious, the credit financing of the enterprise was improved, but the supervision function was not clearly reflected, even compared with other directors. Weak. Liu Chun et al. grasped the market segmentation characteristics of China's local protectionism and found that the function of independent directors in different places is mainly reflected in the use of local social networks to break through barriers to mergers and acquisitions in different places. Through the discussion of the special group that hired independent directors in Beijing, Quanyi (2017) [19] found that listed companies with far-reaching headquarters and Beijing and poor institutional environment at the headquarters are more inclined to hire Beijing to be independent. Directors; Compared with local listed companies in Beijing, the proportion of Beijing independent directors employed by different listed companies in government departments is significantly higher; hiring independent directors in Beijing does help to obtain political resources from listed companies in different places, which is helpful to enterprises. Equity refinancing, entering the high barrier industry and reducing the risk of corporate violations.

Through the above-mentioned literature, we found that both domestic and foreign literatures pay less attention to the special phenomenon of re-election of independent directors. Although the term of office was mentioned in the study of the personal characteristics of the independent director, there is no in-depth analysis of the theoretical path of re-appointment, and the re-election phenomenon is rarely mentioned. With the emergence of China's independent director system in listed companies, the emergence of various phenomena in the market for independent directors, continuing theoretical reasoning and empirical testing to explain the phenomenon of independent directors and further 
guide the development of practice.

\section{Conclusions}

These studies have greatly enhanced people's understanding of the function of independent directors, but there are still two issues to be improved. First, endogenous problems severely constrain the effectiveness of research and lead to biased conclusions. One outstanding performance is that the relationship between independent directors and company value has not been determined so far: Rosenstein \& Wyatt (1990), Wang Yuetang found that independent directors help to enhance the company's value, but Klein (1998) [20] found that the two are irrelevant. And Agrawal \& Knoeber (1996) [21] even found that the proportion of independent directors reduced the value of the company. The above research found that the root cause of the inconsistency is that the structure of the board of directors is neglected by the characteristics of the company, and the characteristics of the company also determine the independence of the board.

What kind of function and how it affects the value of the company (Coles et al., 2008). Therefore, to identify the causal influence and role of independent directors on company value, it is necessary to use the research design of natural experiments (Adams et al., 2010).

Second, most of the existing research follows the perspective of developed markets, and pays insufficient attention to the uniqueness and variability of the issue of independent directors in emerging markets. The institutional environment at the national level has a decisive influence on corporate governance at the micro level (Willison, 2000 [22]): The institutional environment is different and the function of governance mechanisms may mutate. For example, external audit was originally a mechanism for managing agency problems, but China's IPO audit system has induced listed companies to hire accounting firms with audit backgrounds to improve the rate of meetings. Auditors are "watchdogs". "(dogdog) alienated into a "passport" (Yang, 2013 [23]). In the same way, examining the functions of independent directors cannot be separated from the institutional situation in China that is different from developed markets. For example, Liu Chun et al. (2015) [24] seized the market segmentation characteristics of China's local protectionism and found that the function of independent directors in different places is mainly reflected in the use of local social networks to break through barriers to mergers and acquisitions in different places. However, the accumulation of research in this area is still in the morning.

\section{Conflicts of Interest}

The author declares no conflicts of interest regarding the publication of this paper.

\section{References}

[1] Fama, E.F. and Jensen, M.C. (1983) Separation of Ownership and Control. Journal 
of Law and Economics, 26, 301-325. https://doi.org/10.1086/467037

[2] Mace, M.L. (1986) Directors: Myth and Reality. Harvard Business School Press, Boston.

[3] Drucker, P.F. (1955) The Practice of Management. Heinemann, London.

[4] Cotter, J.F., Shivdasani, A. and Zenner, M. (1997) Do Independent Directors Enhance Target Shareholder Wealth during Tender Offers? Journal of Financial Economics, 43, 195-218. https://doi.org/10.1016/S0304-405X(96)00886-0

[5] Weisbach, M.S. (1988) Outside Directors and CEO Turnover. Journal of Financial Economics, 20, 431-460. https://doi.org/10.1016/0304-405X(88)90053-0

[6] Bhagat, S. and Black, B. (2002) Non-Correlation between Board Independence and Long-Term Firm. Journal of Corporation Law, 27, 231-273.

[7] Hermalin, B.E. and Weisbach, M.S. (1998) Endogenously Chosen Boards of Directors and Their Monitoring of the CEO. American Economic Review, 88, 96-118.

[8] Pettigrew, A.M. (1992) On Studying Managerial Elites. Strategic Management Journal, 13, 163-182. https://doi.org/10.1002/smj.4250130911

[9] Brickley, J.A., Coles, J.L. and Terry, R.L. (1994) Outside Directors and the Adoption of Poison Pills. Journal of Financial Economics, 35, 371-390. https://doi.org/10.1016/0304-405X(94)90038-8

[10] Peng, M.W. (2004) Outside Directors and Firm Performance during Institutional Transitions. Strategic Management Journal, 25, 453-471. https://doi.org/10.1002/smj.390

[11] Adams, R.B. and Ferreira, D. (2007) A Theory of Friendly Boards. Journal of Finance, 62, 217-250. https://doi.org/10.1111/j.1540-6261.2007.01206.x

[12] Adams, R.B., Hermalin, B.E. and Weisbach, M.S. (2010) The Role of Boards of Directors in Corporate Governance: A Conceptual Framework and Survey. Journal of Economic Literature, 48, 58-107. https://doi.org/10.1257/jel.48.1.58

[13] Core, J.E., Holthausen, R.W. and Larcker, D.F. (1999) Corporate Governance, Chief Executive Officer Compensation, and Firm Performance. Journal of Financial Economics, 51, 371-406. https://doi.org/10.1016/S0304-405X(98)00058-0

[14] Rosenstein, S. and Wyatt, J.G. (1990) Outside Directors, Board Independence, and Shareholder Wealth. Journal of Financial Economics, 26, 175-191.

https://doi.org/10.1016/0304-405X(90)90002-H

[15] Fich, E.M. and Shivdasani, A. (2007) Financial Fraud, Director Reputation and Shareholder Wealth. Journal of Financial Economics, 86, 306-336. https://doi.org/10.1016/j.jfineco.2006.05.012

[16] DeFond, M.L., Hann, R.N. and Hu, X. (2005) Does the Market Value Financial Expertise on Audit Committees of Boards of Directors? Journal of Accounting Research, 43, 153-193. https://doi.org/10.1111/j.1475-679x.2005.00166.x

[17] Demb, A. and Neubauer, F.F. (1992) The Corporate Board: Confronting the Paradoxes. Oxford University Press, Oxford, New York, Toronto and Melbourne.

[18] Coles, J.L., Daniel, N.D. and Naveen, L. (2008) Boards: Does One Size Fit All? Journal of Financial Economics, 87, 329-356. https://doi.org/10.1016/j.jfineco.2006.08.008

[19] Quan, Y. and Li, S.H. (2017) Do Academic Independent Directors Get Tougher Punishment Because of Their Violation Behaviors China. Journal of Accounting Research, 10, 71-86. https://doi.org/10.1016/j.cjar.2016.10.002

[20] Klein, A. (1998) Firm Performance and Board Committee Structure. Journal of Law 
and Economics, 41, 275-304. https://doi.org/10.1086/467391

[21] Agrawal, A. and Knoeber, C.R. (1996) Firm Performance and Mechanisms to Control Agency Problems between Managers and Shareholders. Journal of Financial and Quantitative Analysis, 31, 377-397. https://doi.org/10.2307/2331397

[22] Williamson, O.E. (2000) The New Institutional Economics: Taking Stock, Looking Ahead. Journal of Economic Literature, 38, 595-613. https://doi.org/10.1257/jel.38.3.595

[23] Yang, Z. (2013) Do Political Connections Add Value to Audit Firms? Evidence from IPO Audits in China. Contemporary Accounting Research, 30, 891-921. https://doi.org/10.1111/j.1911-3846.2012.01177.x

[24] Liu, H., Meng, L. and Zhang, J. (2015) Why Do Entrepreneurs Enter Politics? Evidence from China. Economic Inquiry, 44, 559-578.

https://doi.org/10.1093/ei/cbj031 